\title{
The S-Shaped Relationship Between Internationalization and Performance: Empirical Evidence from Laos
}

\author{
Tu Anh PHAN ${ }^{1}$, Thuy Thi Kim NGUYEN² ${ }^{2}$ Triet Minh PHAN ${ }^{3}$
}

Received: August 01, 2020 Revised: September 20, 2020 Accepted: October 05, 2020

\begin{abstract}
The purpose of this study is to investigate the impact of internationalization on the business performance of firms in Laos as a transition economy. Using a panel dataset collected by the World Bank for 285 firms during the period 2009, 2012, and 2016 in the service and manufacturing industries, the two-steps Heckman regression results found robust evidence for the fact that the S-curve tie exists between the degree of internationalization and business performance of firms in Laos while controlling other factors. Specifically, if firms have a degree of internationalization lower than 0.4374 , they will suffer losses due to the high cost of preparing for phase 1 which is market penetration. Then, when the degree of internationalization continues to increase from 0.4374 to 0.9131 , firms will gain benefits from internationalization (phase 2), however, these benefits will deteriorate when the degree of internationalization is greater than 0.9131 (phase 3), meaning that firms will no longer be able to exploit economies of scale or advantages in target markets, or product cycles will fall into a state of decline. Interestingly, we also found that firms with a high concentration level of ownership and internationalization activities may achieve better performance than those with a low concentration of ownership and one which carried out internationalization activities.
\end{abstract}

Keywords: Internationalization, Business Performance, S-Curve, Heckman, Laos

JEL Classification Code: F14, F23, M16

\section{Introduction}

Internationalizing businesses in the context of openness and international economic integration can benefit businesses such as market share, growth, and innovation ( $\mathrm{Lu}$ $\&$ Beamish, 2001), especially for developing and emerging economies (Sanyal, Hisam, \& Baawain, 2020). However, internationalization also poses challenges for businesses to survive in a complex and globally competitive environment. Expansion into new international markets is always related

${ }^{1}$ First Author and Corresponding Author. Chair, Department of International Business, College of Economics, Can Tho University, Vietnam [Postal Address: 3/2 Street, Campus 2, Ninh Kieu District, Can Tho City, Can Tho Province, 900000, Vietnam]

Email: patu@ctu.edu.vn

2Staff, Bien Dong Seafood Ltd., Can Tho City, Vietnam.

Email: kimthuyskr@gmail.com

${ }^{3}$ Faculty of Arts, University of Waterloo, Canada.

Email:m5phan@uwaterloo.ca

(c) Copyright: The Author(s)

This is an Open Access article distributed under the terms of the Creative Commons Attribution Non-Commercial License (https://creativecommons.org/licenses/by-nc/4.0/) which permits unrestricted non-commercial use, distribution, and reproduction in any medium, provided the original work is properly cited. to the cost of adapting to the foreign environment, and this leads to changes in the organizational structure of the business (Sui \& Baum, 2014), difficulties related to liabilities of foreignness (Hymer, 1976), and newness (Stinchcombe, 1965). Moreover, when running a business abroad, increase in costs, including transaction costs, due to new regulations and other issues in operating business activities in the host country (Lu \& Beamish, 2004). Liability of foreignness refers to the fact that new firms entering international markets often lack knowledge about local markets, lack of cultural understanding, lack of information in the host country, and subject to discrimination by government, customers, and even suppliers ( $\mathrm{Li}, 2007)$.

Therefore, the relationship between internationalization and business performance has always attracted many researchers and practitioners in the field of international business administration (Glaum \& Oesterle, 2007; Contractor, 2012). Numerous empirical studies have found that a high degree of internationalization improves business performance significantly (Zahra, Ireland, \& Hitt, 2000). On the contrary, some studies find a negative relationship between internationalization and business performance (Michel \& Shaked, 1986). On the other hand, a few studies 
have found evidence that a non-linear relationship exists, such as a U-shaped (Lu \& Beamish, 2001; Contractor, Kumar, \& Kundu, 2007), inverted U-shaped (Hitt, Hoskisson, \& Kim, 1997), and a few studies found the S-shaped (Contractor, Kundu, \& Hsu, 2003; Lu \& Beamish, 2004), M ( M-curve) (Almodóvar \& Rugman, 2014) and letter W shaped (Fernández-Olmos, Gargallo-Castel, \& Giner-Bagües, 2016). This relationship is not merely having positive or negative effects (Chung, Lee, Beamish, Southam, \& Nam, 2013). Therefore, the prognosis from the impact of the theory-based predictions of the business theory has not yet reached consensus from research scholars. Some of the reasons are that previous studies mostly used theory and control in developed countries (Xiao, Jeong, Moon, Chung, \& Chung, 2013; Peng, Wang, \& Jiang, 2008). Second, many studies that have performed descriptive statistics and using cross sectional data instead of longitudinal studies will better reflect the dynamic nature of internationalization activities (Chiao, Yang, \& Yu, 2006).

A few empirical studies have found evidence of a horizontal (three-stage) S-shaped relationship when describing the relationship between internationalization and business performance in emerging economies (Contractor et al., 2003; Lu \& Beamish, 2004). Internationalization is considered as one of the successful strategies of businesses in the emerging economy when they can explore and make good use of opportunities in the global market and create competitive advantages (Guillen \& Garcia-Canal, 2009). Therefore, to add empirical data and the theoretical basis on the relationship of internationalization and business performance, especially enterprises in emerging economies such as Laos, the objective of this paper using panel data to analyze whether or not an S-shaped relationship exists between the degree of internationalization and business performance of manufacturing and service firms in Laos.

Laos emerged as a participating country after being removed by the US embargo list in 2009, but Laos' policy continues to promote economic development and participate in globalization. In the period 2006 - 2018, Laos' exports showed signs of growth but they were quite volatile; this is an indication that the Laos government is accelerating the globalization process step by step. The government's export support policies gradually created an incentive for businesses in Laos to take steps to improve their business efficiency in the process of internationalization. Therefore, it is necessary to study the role of internationalization and business performance for a country with an emerging economy like Laos and contribute additional information which supports the theory of internationalization and business performance in emerging economies.

The remainder of the paper is organized into five sections. Section 2 describes literature review and hypotheses. In Section 3, we present a brief description of the sample and measurement. Section 4 presents the descriptive statistics, correlation, and regression results while the conclusion is reported in Section 5.

\section{Theoretical Framework and Hypotheses}

One of the first and best-known theories about internationalization is the "Internationalization process" theory, which has two other names, "Stage Model" or "Uppsala Model," which has been studied by Johanson \& Vahlne (1977). According to this theory, internationalization is a four-stage process in which firms make continuous efforts to increase participation and sharing in international markets, while gradually improving foreign consumers' awareness and commitment to their products. Specifically, for the first stage, enterprises operate in the home market and do not participate in export activities. In the next stage, businesses began to consider expanding the crossborder business by exporting through representatives or agents. In the third stage, as it involves binding resources in the international market, firms often set up a sales branch overseas and build a manufacturing facility in foreign countries in the final stage. Therefore, business performance will also vary according to each stage of business internationalization. Specifically, the relationship between internationalization strategy and business performance is in the S-shape. According to this S-shape, in the early stages of the company's performance decreases due to the accumulation of experience in internationalization is at a low and high level of internationalization but with moderate increases, especially suitable for transition economies such as Laos (Contractor, 2012).

Phase 1: Underdeveloped or emerging economies have low competitiveness compared to developed countries (Porter, 1990), most of which rely on available resources to export raw materials (Thomas, 2006) and in order to compete in international markets internationalization firms often sell goods at low prices to enter new markets ( Xiao et al., 2013). Consequently, internationalization in the early stages often incurs more costs to the business, such as liability of foreignness, legitimacy, and newness. Enterprises in Laos still mainly produce agricultural products and textile products based on outsourcing, so they will have to spend more money on market research problems, search, and penetration. Therefore, corporate profits often drop in the first years of internationalization.

Phase 2: Over time, these businesses begin to have economic benefits, initial success, and then start to increase sales, receive value for money and knowledge of building real estate. These factors contribute to corporate profits (Grant, Jammine, \& Thomas, 1988; Lu \& Beamish, 2001). However, this is only a short-term period, the primary advantages from the destination countries will quickly disappear as products 
created by enterprises will gradually be replaced by domestic enterprises, so the competition increases and makes the profitability of the business complicated to maintain the advantage in the long-term.

Phase 3: The problem arises when too much internationalization will lead to an increase in the cost of both the ownership structure and the corporate governance problem, therefore there is a rise in the costs and as a result businesses become less efficient than before (Chung, Lu, \& Beamish, 2008). The growth characteristics of Laos enterprises are mainly limited to exploiting competitiveness based on the export of raw materials, cheap labor advantage, and export or product processing for partner countries. Thus, moving towards a high level of internationalization or switching to proactive exports entirely means that businesses in Laos have to find and exploit new markets by themselves, while undertaking the domestic activities at the same time. Therefore, costs and risks will increase in the case of firms actively exporting entirely, and this causes the firm's profit to decline compared to the previous period.

$\boldsymbol{H}_{i}$ : The degree of internationalization influencing business performance of enterprises in Laos has a horizontal S-curved shape.

\section{Research Method}

The study uses secondary data surveyed by the World Bank to improve the business environment as a critical strategy to contribute to the economic development and develop a data set for businesses in countries around the world. Enterprise Surveys covers 155,000 businesses in 148 countries. The Kingdom of Laos has been surveyed by ES through 3 years 2009, 2012, and 2016 with the number of surveyed enterprises respectively 360,379 , and 368 to consider the contribution of the level of internationalization to business performance over time, the study uses tabular data including 95 enterprises surveyed repeatedly over three years. The number of observations of the study is 285 observations and also uses the number to provide an overall result for the economy of Laos.

\subsection{Estimation Method}

Each enterprise was surveyed over the past three years, respectively, in 2009, 2012, and 2016; each year, the company conducted activities that carried out internationalization (export) or did not show any behavior that indicated the company undertook an internationalization year. In other words, the data set of enterprises internationalization is limited, so the collected samples will be optional and therefore biased due to the missing factors and the sample selection method, and this will lead to the problem of bias in regression estimation (Heckman, 1979). Then, instead of applying methods for the regression of table data such as FEM (fixed effects) or REM (random effects), the article will use the 2-step Heckman regression method (Xiao et al., 2013; Chung et al., 2010; Woolbridge, 1995) as follows:

Theoretically, Heckman (1977) identified two steps that needed to be taken to overcome the bias in sample selection problem, in which, step 1 refers to the Probit model in order to remove any unconditional observations

With:

$$
y_{1}=\left\{1 \text { if } y^{*}>00 \text { if } y^{*} \leq 0\right.
$$

$$
y_{1 i}=\beta_{1} x_{1 i}^{\prime}+\varepsilon_{i}
$$

Using the value of $y_{1}$ as the independent variable in the OLS model is the second step that Heckman mentions:

$$
y_{2 i}=x_{2 i}^{\prime} \beta_{2}+\sigma_{12} \lambda\left(x_{1 i}^{\prime} \widehat{\beta}_{1}\right)+v_{i}
$$

Thus, the redetermination of the number of observations can be based on the conditions of the dependent variable or the independent variable. As equation (2.3) the independent variable is used as a condition to redefine the sample size and use it as a factor affecting another result $\left(\mathrm{y}_{2}\right)$ (Cameron $\&$ Trivedi, 2005). Therefore, according to Xiao et al (2013) and Woolbridge (1995), we built a two-step Heckman implementation process as follows:

Step 1: Set up an independent variable group consisting of the variables used in the model in step 2, however this group of variables should be limited to a number of variables different from the model in step 2 to avoid problems of determining the regression. The model used in step 1 is the Probit model for all enterprises surveyed in Laos in year $t=(2009,2012,2016)$, from the regression results, the author calculated the inverse Mills index for each enterprise in year $t$, then:

$$
\lambda_{i t}=\frac{\phi(x)}{\Phi(x)}
$$

Where: $\lambda_{i t}$ is the inverse Mills value of firm i in year $\mathrm{t}, \phi(x)$ is the value of the normal distribution density function, $\Phi(x)$ is the value of the cumulative distribution density function. Estimated model in step 1:

$$
\begin{aligned}
P\left(\text { progress }_{i t}=\right. & 1) \\
= & \Phi\left(\beta_{0}+\beta_{1} \operatorname{SIZE}_{i t}+\beta_{2} \text { LABOR }_{i t}+\beta_{3} A G E_{i t}\right. \\
& +\beta_{4} C E N T R A L_{i t}+\beta_{5} C \operatorname{CREDIT}_{i t} \\
& \left.+\beta_{6} \operatorname{COMP}_{i t}+\varepsilon_{I}\right)
\end{aligned}
$$


Step 2: Regression of OLS with inverse Mills value, but to correct the phenomenon of series correlation and variance change, we perform regression according to Newey - West method to correct error (Newey \& West, 1987).

$$
\begin{aligned}
\operatorname{ROS}_{i t}= & \beta_{0}+\beta_{1} \text { DOI }_{i t}+\beta_{2} \text { DOI }_{i t}^{2}+\beta_{3} \text { DOI }_{i t}^{3}+\beta_{4} \text { CENTRAL }_{i t} \\
& +\beta_{5} \text { EXCHANGE }_{i t}+\beta_{6} C R E D I T_{i t}+\beta_{7} C O M P_{i t} \\
& +\beta_{8} \text { AGE }_{i t}+\beta_{9} \text { SIZE }_{i t}+\beta_{10} \text { LABOR }_{i t}+\beta_{11} I N T E R 1_{i t} \\
& +\beta_{12} \text { INTER }_{i t}+\beta_{13} \lambda_{i t}+u_{i t}
\end{aligned}
$$

Where:

- ROS: The Company's profit-to-revenue ratio represents its business performance.

- $\beta_{0}$ is the intercept of the model

- $\beta_{1} \rightarrow \beta_{13}$ : respectively estimated coefficients of variables in the model, including independent variables and control variables.

- $\lambda$ is the inverse Mills factor, determined from step 1

- $\mathrm{i}$ is the $\mathrm{i}$ firm to be surveyed

- $\mathrm{t}$ is the year, 2009, 2012 and 2016

- $\varepsilon_{\mathrm{it}}$ and $\mathrm{u}_{\mathrm{it}}$ : are the model errors

ROS (dependent variable): measured as a ratio of return on sales (Do, 2020; Xiao et al., 2013).

DOI (Degree of Internationalization): We choose the export value over total sales as a proxy for the degree of internationalization of the firm (Capar \& Kotabe, 2003).

CENTRAL (Firm ownership concentration): uses the value of the majority holder's shareholding rate to consider the impact on the business performance of the business in case there is internationalization.

CREDIT (ratio of credit capital): Credit loans in Laos are extremely difficult, while this is an important factor to help businesses operate effectively. We use the value of credit as the ratio of capital purchased by suppliers and customer advances as a representative value of credit that is accessed rather than used from the company's own funds.

SIZE (revenue) and LABOR (number of employees) (Nguyen \& Nguyen, 2020; Xiao et al., 2013; Contractor et al., 2003) use a firm's gross revenue as a proxy for firm size. Many empirical results show that large-scale enterprises will begin to expand their markets to other countries instead of just exploiting the domestic market because products are cyclical, and maintaining profitability or expanding profit value requires businesses to change markets to get better advantages. Values are taken from the natural logarithm.

AGE (years of operation of the enterprise) is measured from the enterprise's establishment to the survey in 2009, 2012, and 2016.

COMP (firm's level of competition): The highly competitive business will seek ways to adapt to the competitive environment. We use the coefficient of variation of revenue over three years to represent the competitive level of the business, if the value is higher, the business is highly competitive and vice versa.

INTER1: interaction between the level of corporate management centralization and internationalization.

\begin{tabular}{|c|c|c|}
\hline Variables & Measurement & Expectation \\
\hline ROS & Return on total sales & \\
\hline $\mathrm{DOI}$ & $\begin{array}{l}\text { Direct exports and Indirect exports (sold domestically to a third party that exports } \\
\text { products) per total sales. }\end{array}$ & - \\
\hline $\mathrm{DOI} 2$ & DOI squared. & + \\
\hline DOI3 & DOI cubic. & - \\
\hline CENTRAL & Percentage held by largest owner or owners (\%). & - \\
\hline CREDIT & Purchases on credit from suppliers and advances from customers. & + \\
\hline INTER1 & Interaction term between CENTRAL and DOI. & + \\
\hline INTER2 & Interaction term between CREDIT and DOI. & + \\
\hline COMP & Average of last complete fiscal year's total sales and Total annual sales three years ago. & + \\
\hline AGE & Year - Year establishment began operations. & + \\
\hline SIZE & Logarit của doanh thu của doanh nghiệp. & + \\
\hline LABOR & Logarit của lao động tham gia sản xuất của công ty. & + \\
\hline EXCHANGE & Nominal Exchange Rate between LAK and USD. & + \\
\hline $\mathrm{D}$ & Dummy for location. & \\
\hline $\mathrm{T}$ & Time dummy (2012 and 2016). & \\
\hline
\end{tabular}

INTER2: interaction between the rate of credit borrowed by the business and internationalization (See Table 1).

Table 1: Interpretation of the variables in the model 


\section{Result and Discussions}

To conduct a regression analysis to find the relationship between the degree of internationalization and the business performance of businesses in Laos, we use internal and external variables. Firstly, we provide the statistical results that describe the group of variables used in the model in Table 2. As mentioned, all businesses in Laos are private, operating in a family tradition and still small in scale, so there is no high degree of internationalization, the average value of DOI is only about 0.16 . Firm ownership concentration is measured as the majority of capital holdings in the firm, which is of very high value because almost all businesses in Laos are private. The number of years of operation
(AGE) of the business used for analysis has a long history of the establishment. However, the number of firms using formal credit to expand production is extremely low. The variables with Spearman correlation coefficients are all less than 0.6 , so it can be said that there is no doubt that the multicollinearity phenomenon appears in the model (See Table 2).

By the time of the survey, the corresponding number of observations for the years 2009, 2012 and 2016, about 359,334 , and 362 observations, these enterprises, if having direct and indirect export activities, are considered to have behaviors which undertakes internationalization for the year and therefore is encoded as progress $=1$; otherwise, it encodes progress $=0($ See Table 3$)$.

Table 2: Correlation (Bivariate Pearson)

\begin{tabular}{|l|c|c|c|c|c|c|c|c|c|c|}
\hline & Mean & S.D & $(\mathbf{1})$ & $\mathbf{( 2 )}$ & $\mathbf{( 3 )}$ & $\mathbf{( 4 )}$ & $\mathbf{( 5 )}$ & $\mathbf{( 6 )}$ & $\mathbf{( 7 )}$ & $\mathbf{( 8 )}$ \\
\hline (1) ROS & 0,56 & 0,28 & 1 & & & & & & & \\
\hline (2) DOI & 0,15 & 0,32 & $-0,152^{*}$ & 1 & & & & & & \\
\hline (3) CENTRAL & 0,98 & 0,10 & $-0,041$ & 0,027 & 1 & & & & & \\
\hline (4) CREDIT & 0,02 & 0,10 & $0,141^{*}$ & 0,028 & 0,045 & 1 & & & & \\
\hline (5) AGE & 14,46 & 10,29 & 0,105 & $-0,074$ & $-0,002$ & 0,018 & 1 & & & \\
\hline (6) SIZE & 20,54 & 3,37 & $0,127^{*}$ & 0,101 & $-0,098$ & $-0,019$ & 0,098 & 1 & & \\
\hline (7) LABOR & 3,05 & 1,40 & $-0,214^{*}$ & $0,488^{*}$ & $-0,144^{*}$ & $-0,107$ & $-0,021$ & $0,246^{*}$ & 1 & \\
\hline (8) COMP & 0,45 & 0,51 & 0,056 & 0,037 & $-0,174^{*}$ & $0,166^{*}$ & $-0,004$ & $0,424^{*}$ & $-0,054$ & 1 \\
\hline (9) EXCHANGE & $8.219,39$ & 213,42 & $-0,372^{*}$ & $-0,053$ & 0,042 & $-0,208^{*}$ & $-0,096$ & $0,182^{*}$ & 0,079 & $-0,261^{*}$ \\
\hline
\end{tabular}

Note: *: Pearson's correlation coefficient is statistically significant at the $5 \%$ level; ROS: return on sales; DOI: degree of internationalization; CENTRAL: centralization; CREDIT: ratio of credit capital; AGE: years of operation of the enterprise; SIZE: business size (logarithm of revenue); LABOR: quantity of labor (taking logarithmic value); COMP: the level of competition of the business; EXCHANGE: exchange rate.

Table 3: Probit model (D.V = Progress)

\begin{tabular}{|l|c|c|c|}
\hline Independent variables & $\begin{array}{c}\text { Progress } \\
(\mathbf{2 0 0 9 )}\end{array}$ & $\begin{array}{c}\text { Progress } \\
(\mathbf{2 0 1 2})\end{array}$ & $\begin{array}{c}\text { Progress } \\
(\mathbf{2 0 1 6})\end{array}$ \\
\hline SIZE & $-0,303^{* * *}$ & $-0,008$ & $-0,011$ \\
& $(-4,61)$ & $(-0,41)$ & $(-0,10)$ \\
\hline LABOR & $0,761^{* * *}$ & $0,434^{* * *}$ & $0,615^{* * *}$ \\
& $(7,65)$ & $(6,53)$ & $(4,79)$ \\
\hline AGE & 0,009 & $-0,003$ & $-0,018$ \\
& $(0,83)$ & $(-0,30)$ & 0,427 \\
\hline CREDIT & $3,354^{* *}$ & 0,485 & $(0,45)$ \\
\hline CENTRAL & $(2,08)$ & $(1,10)$ & 0,782 \\
& 0,674 & $1,512^{* *}$ & $(1,18)$ \\
\hline COMP & $(0,79)$ & $(2,01)$ & $-0,190$ \\
& $0,534^{* *}$ & $0,297^{* *}$ & $(-0,57)$ \\
\hline Cons & $(2,49)$ & $(2,09)$ & $-3,364$ \\
& 2,046 & $-3,685^{* * *}$ & $(-1,61)$ \\
\hline $\mathrm{N}$ & $(1,42)$ & $(-4,12)$ & 368 \\
\hline P-value & 359 & 379 & 0,000 \\
\hline
\end{tabular}

Note: the number in parentheses is a $z$ value; ${ }^{*} p<0.1 ;{ }^{* *}: p<0.05 ;{ }^{* * *}$ : $p<0.01$. SIZE: business size, LABOR: workforce; AGE: years of operation; CREDIT: the ratio of credit capital of the business to access; CENTRAL: concentration ratio of ownership of business value; COMP: the level of competition of the business; PROGRESS: business has internationalization. 
Table 4: Two-steps Heckman Regression

\begin{tabular}{|c|c|c|c|c|c|c|}
\hline Independent variables & $\begin{array}{l}\text { ROS } \\
\text { (1) }\end{array}$ & $\begin{array}{l}\text { ROS } \\
(2)\end{array}$ & $\begin{array}{c}\text { ROS } \\
\text { (3) }\end{array}$ & $\begin{array}{l}\text { ROS } \\
\text { (4) }\end{array}$ & $\begin{array}{c}\text { ROS } \\
\text { (5) }\end{array}$ & $\begin{array}{c}\text { ROS } \\
\text { (6) }\end{array}$ \\
\hline MILL_2009 & $\begin{array}{c}0,433^{* *} \\
(2,30)\end{array}$ & $\begin{array}{c}0,408^{* *} \\
(2,03)\end{array}$ & $\begin{array}{c}0,402^{\star *} \\
(2,00)\end{array}$ & $\begin{array}{c}0,406^{* *} \\
(2,03)\end{array}$ & $\begin{array}{l}0,388^{*} \\
(1,92)\end{array}$ & $\begin{array}{l}0,392^{*} \\
(1,91)\end{array}$ \\
\hline MILL_2012 & $\begin{array}{l}-0,179 \\
(-0,65)\end{array}$ & $\begin{array}{l}-0,098 \\
(-0,30)\end{array}$ & $\begin{array}{l}-0,078 \\
(-0,24)\end{array}$ & $\begin{array}{l}0,107 \\
(0,32)\end{array}$ & $\begin{array}{l}0,158 \\
(0,47)\end{array}$ & $\begin{array}{l}0,166 \\
(0,49)\end{array}$ \\
\hline MILL_2016 & $\begin{array}{l}-0,223 \\
(-1,46)\end{array}$ & $\begin{array}{l}-0,257 \\
(-1,54)\end{array}$ & $\begin{array}{l}-0,259 \\
(-1,55)\end{array}$ & $\begin{array}{c}-0,378^{\star *} \\
(-2,08)\end{array}$ & $\begin{array}{c}-0,403^{* *} \\
(-2,18)\end{array}$ & $\begin{array}{c}-0,415^{* *} \\
(-2,15)\end{array}$ \\
\hline SIZE & $\begin{array}{c}0,050^{* *} \\
(2,21)\end{array}$ & $\begin{array}{c}0,052^{* *} \\
(2,22)\end{array}$ & $\begin{array}{c}0,053^{* *} \\
(2,24)\end{array}$ & $\begin{array}{c}0,054^{* *} \\
(2,28)\end{array}$ & $\begin{array}{c}0,056^{* *} \\
(2,34)\end{array}$ & $\begin{array}{c}0,055^{* *} \\
(2,30)\end{array}$ \\
\hline LABOR & $\begin{array}{c}-0,078^{* * *} \\
(-2,73)\end{array}$ & $\begin{array}{c}-0,076^{* * *} \\
(-2,69)\end{array}$ & $\begin{array}{c}-0,074^{\star *} \\
(-2,58)\end{array}$ & $\begin{array}{c}-0,062^{* *} \\
(-2,12)\end{array}$ & $\begin{array}{c}-0,064^{* *} \\
(-2,16)\end{array}$ & $\begin{array}{c}-0,064^{* *} \\
(-2,15)\end{array}$ \\
\hline AGE & $\begin{array}{l}0,002 \\
(0,91)\end{array}$ & $\begin{array}{l}0,002 \\
(0,85)\end{array}$ & $\begin{array}{l}0,002 \\
(0,84)\end{array}$ & $\begin{array}{l}0,002 \\
(0,86)\end{array}$ & $\begin{array}{l}0,002 \\
(0,84)\end{array}$ & $\begin{array}{l}0,002 \\
(0,84)\end{array}$ \\
\hline CREDIT & $\begin{array}{c}0,875^{\star * *} \\
(2,77)\end{array}$ & $\begin{array}{c}0,843^{* *} \\
(2,56)\end{array}$ & $\begin{array}{c}0,838^{\star *} \\
(2,53)\end{array}$ & $\begin{array}{c}0,858^{* *} \\
(2,59)\end{array}$ & $\begin{array}{c}0,835^{* *} \\
(2,50)\end{array}$ & $\begin{array}{c}0,830^{* *} \\
(2,52)\end{array}$ \\
\hline CENTRAL & $\begin{array}{l}-0,138 \\
(-1,24) \\
\end{array}$ & $\begin{array}{l}-0,110 \\
(-0,92) \\
\end{array}$ & $\begin{array}{c}-0,10 \\
(-0,84) \\
\end{array}$ & $\begin{array}{l}-0,023 \\
(-0,19) \\
\end{array}$ & $\begin{array}{l}-0,039 \\
(-0,32) \\
\end{array}$ & $\begin{array}{l}-0,036 \\
(-0,29) \\
\end{array}$ \\
\hline COMP & $\begin{array}{l}0,057 \\
(1,18)\end{array}$ & $\begin{array}{l}0,065 \\
(1,30)\end{array}$ & $\begin{array}{l}0,066 \\
(1,31)\end{array}$ & $\begin{array}{l}0,099^{*} \\
(1,85)\end{array}$ & $\begin{array}{l}0,102^{*} \\
(1,90)\end{array}$ & $\begin{array}{l}0,105^{*} \\
(1,88)\end{array}$ \\
\hline EXCHANGE & $\begin{array}{c}-0,0007^{\star \star \star \star} \\
(-6,62)\end{array}$ & $\begin{array}{c}-0,0007^{* * *} \\
(-6,59)\end{array}$ & $\begin{array}{c}-0,0007^{* * *} \\
(-6,58)\end{array}$ & $\begin{array}{c}-0,0007^{* * *} \\
(-6,55)\end{array}$ & $\begin{array}{c}-0,0007^{* * *} \\
(-6,46)\end{array}$ & $\begin{array}{c}-0,0007^{* * \star} \\
(-6,46)\end{array}$ \\
\hline $\mathrm{DOI}$ & & $\begin{array}{l}-0,053 \\
(-0,59)\end{array}$ & $\begin{array}{l}-0,159 \\
(-0,49)\end{array}$ & $\begin{array}{c}-1,660^{* *} \\
(-2,11)\end{array}$ & $\begin{array}{c}-2,158^{* *} \\
(-2,56)\end{array}$ & $\begin{array}{c}-2,146^{* *} \\
(-2,53)\end{array}$ \\
\hline DOI2 & & & $\begin{array}{l}0,090 \\
(0,31)\end{array}$ & $\begin{array}{c}3,924^{* *} \\
(1,98)\end{array}$ & $\begin{array}{c}3,991^{* *} \\
(2,00)\end{array}$ & $\begin{array}{l}3,918^{*} \\
(1,94)\end{array}$ \\
\hline DOI3 & & & & $\begin{array}{c}-2,469^{*} \\
(-1,92)\end{array}$ & $\begin{array}{c}-2,496^{*} \\
(-1,92)\end{array}$ & $\begin{array}{c}-2,438^{*} \\
(-1,86)\end{array}$ \\
\hline INTER1 & & & & & $\begin{array}{c}0,456^{* *} \\
(2,26)\end{array}$ & $\begin{array}{c}0,458^{* *} \\
(2,26)\end{array}$ \\
\hline INTER2 & & & & & & $\begin{array}{l}0,111 \\
(0,25)\end{array}$ \\
\hline _Cons & $\begin{array}{c}5,650^{\star \star *} \\
(5,82)\end{array}$ & $\begin{array}{c}5,56^{* * *} \\
(5,66)\end{array}$ & $\begin{array}{c}5,54^{* * *} \\
(5,62)\end{array}$ & $\begin{array}{c}5,42^{* * *} \\
(5,46)\end{array}$ & $\begin{array}{c}5,358^{* * *} \\
(5,44)\end{array}$ & $\begin{array}{l}5,36^{\star * *} \\
(5,32)\end{array}$ \\
\hline $\mathrm{N}$ & 259 & 259 & 259 & 259 & 259 & 259 \\
\hline P-value & 0,000 & 0,000 & 0,000 & 0,000 & 0,000 & 0,000 \\
\hline Heteroskedasticity $(\dagger)$ & 0,067 & 0,074 & 0,070 & 0,079 & 0,101 & 0,110 \\
\hline Autocorrelation (††) & 0,499 & 0,517 & 0,490 & 0,593 & 0,639 & 0,644 \\
\hline
\end{tabular}

Note: the number in parentheses is a $z$ value; *: $p<0.1$; **: $p<0.05 ;{ }^{* * *}: p<0.01$. SIZE: business size, LABOR: workforce; AGE: number of years of operation; CREDIT: the ratio of credit capital of the business to access; CENTRAL: concentration ratio of ownership of business value; COMP: the level of competition of the business; PROGRESS: business has internationalization. 
Tu Anh PHAN, Thuy Thi Kim NGUYEN, Triet Minh PHAN /

According to the results in Table 3, the model of the probability of internationalization of enterprises in 2009 shows that the number of enterprises internationalizing depends on the number of employees being employed by the enterprise. The more the number of the employees, the higher the probability for business to internationalize. On the contrary, the size of the firm based on the number of its turnover has a negative value, which can be explained as follows: in 2009, Laos was lifted from the embargo, so most businesses in Laos still indulged in activities which aimed at exploiting the domestic market, therefore, if an enterprise dominates a better market share in the domestic market, it will continue to exploit this market source instead of looking for other riskier markets.

The model of the probability of internationalization of enterprises in 2012 is different from that of 2009. Specifically, firm size per revenue no longer affects the decision to internationalize businesses. Instead, it is the factor that promotes the internationalization of enterprises - CENTRAL the degree of concentration in ownership of business value, it can be said that in addition to enterprises in Laos operating in industries with fierce competition will motivate them to move to the outside market because they may have accumulated experience in the process of domestic competition, or the internationalization process may have put more competitive pressure on businesses. Besides that if the business is headed by one person or just a few people instead of groups of people, the decision will become quicker and conclusive.

The firm's probabilistic model in 2016 shows that the workforce is the only factor driving firms' internationalization in this country. The remaining factors have no impact, possibly because these enterprises have internationalized in the previous years, and the barrier, as well as the promotion factors, are no longer active or hindering during the internationalization process.

Based on Table 4, the S-shaped relationship is represented in the model (4). Specifically, there are negative effects when considering the linear relationship, the positive effect when considering the nonlinear relationship, and negative when considering cube relationships. This shows that if businesses in Laos go to internationalization, they will incur initial costs of loss that reduces their performance. However, their performance will recover when they go deep in the internationalization process and will go into recession again during a period of high degree of internationalization.

To determine the degree of internationalization impact on business performance of the enterprise, we base on the principle of constant other factors and derive the differential of the model (4) from calculating the Export by Xiao et al. (2013).

$$
\begin{aligned}
\frac{\partial(R O S)}{\partial(D O I)} & =-7,407(D O I-0,1455)^{2} \\
& +7,848(D O I-0,1455)-1,66
\end{aligned}
$$

Equation (1) has 2 solutions, DOI $=0.4374$ and DOI $=$ 0.9131. Thus, it can be said that if businesses in Laos have internationalization levels lower than 0.4374 , they will suffer losses due to the high cost of preparing for phase 1 - market penetration. Then, the level of internationalization continues to increase from 0.4374 to 0.9131 (focusing on exports), businesses will begin to receive benefits from internationalization (phase 2) and later. Later, when internationalization is greater than 0.9131 then it is a stage of high internationalization, but the firm can no longer exploit economies of scale or advantages in target markets, or product cycles fall into a state of decline. However, threshold 2 is the level of very high internationalization and, not many businesses reach this position, so the primary benefits are still the motivation for businesses in Laos to enter the global market (See Figure 1).

Firm ownership concentration ratio $(\beta=-0.036 ; \mathrm{p}>0.1)$ to conduct analysis. Although the results show that a high concentration of ownership will harm the business results of the business, it is not statistically significant. The number of firms with a dispersed share of capital ownership means that joint-stock or foreign joint ventures account for a small proportion and the ability to operate does not stand out, and private firms still have positive incentives compared to the pre-opening period, so there is almost no difference in terms of profitability. The interactive variable to identify a group of enterprises with a high proportion of ownership concentration and internationalization will differ from the rest of the business, INTER1 - an enterprise with a high concentration of ownership and high internationalization $(\beta=0.458$; $p$ $<0.05$ ). Thus, only firms which have a high concentration of ownership that perform internationalization, will operate more efficiently than the rest with or without internationalization. Firms with a high degree of ownership concentration will have two directions: to exploit the domestic market, the other is to target outside markets, and only the outside-oriented firms can achieve more efficiency, this shows that these enterprises are more experienced, accumulate more information, and have a better way to run their businesses to look to the global market; for that reason, domestic competition is ominous and therefore will operate much more efficiently than with other businesses.

The number of years of operation of the enterprise $(\beta=0.002$; $\mathrm{p}>0.10$ ) is not statistically significant, or there is no difference in the performance of enterprises with different business periods, and the number of years of operation. The higher the ratio, the more efficient the business will be, the same result is Tu \& Uyen (2017); it can be said that long-established businesses will have more experience. However, the average number of years of operation of the surveyed firms is 16 years, and most of these firms are of the same size, with their main product being agricultural in nature. These products are outsourced, so they do not have specific characteristics but only aim to exploit the country's comparative advantage, so the number of years of operation does not affect the firms' business performance in Laos. 


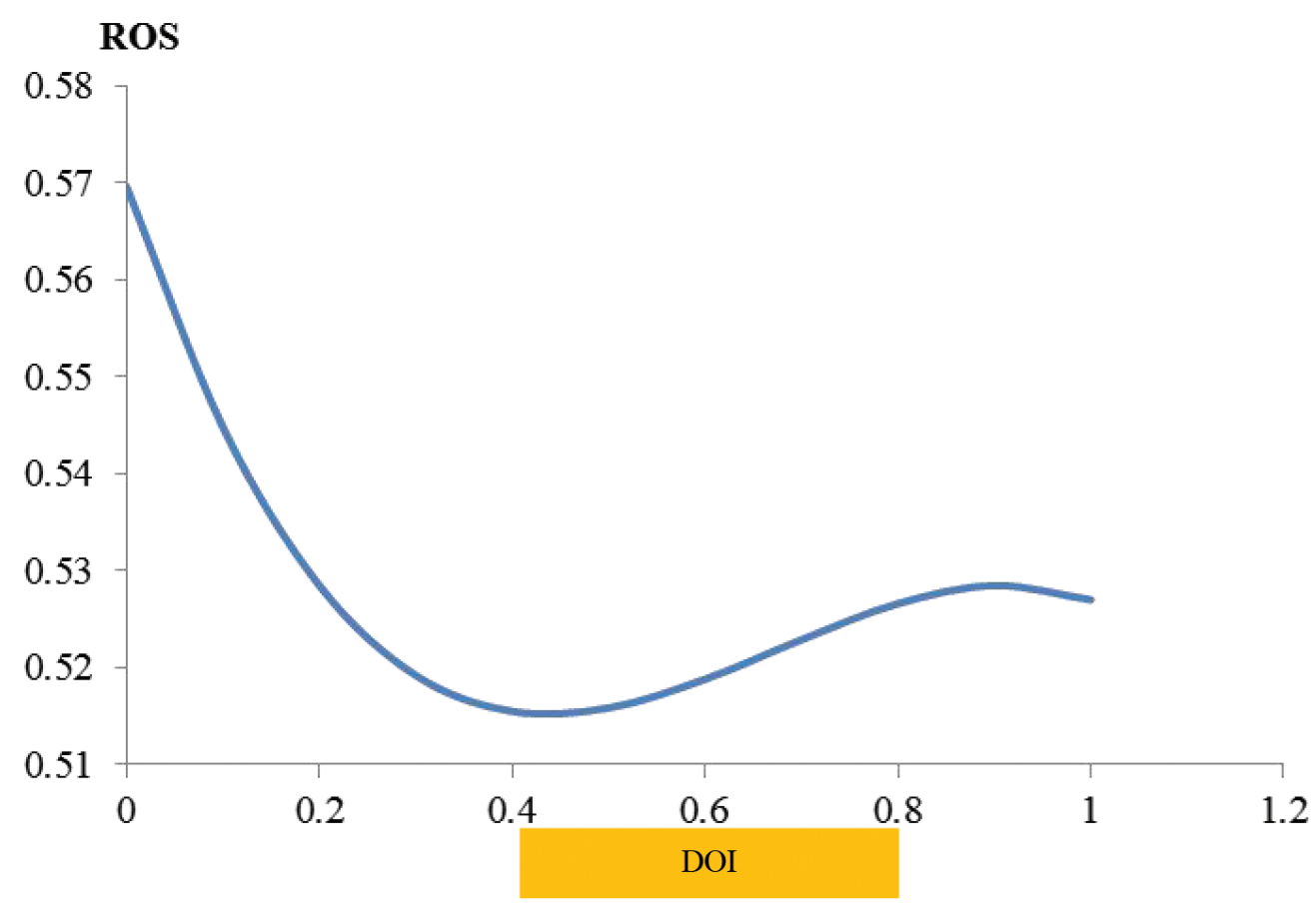

Figure 1: The relationship between internationalization and business performance in Laos followed by the S-shaped.

Firm size $(\beta=0.055 ; \mathrm{p}<0.01)$, the result is similar to the research of Xiao et al. (2013); Fenandez-Olmos et al. (2016); Altaf \& Shah (2015) showed that the bigger the revenue the enterprise has, the more efficiently it will operate, or in other words, businesses in Laos have increased performance.

The level of competition $(\beta=0.105 ; \mathrm{p}<0.10)$ is statistically significant at $10 \%$, or the more profits under the pressure of competition, the more competitive the business environment will bring high profits. This is a trade-off, demonstrating the risk appetite or risk aversion of the head of the business, enterprises operating with each other will have to pay more costs for supporting activities such as promoting their property ( since more than $50 \%$ of businesses in Laos are retailers). Therefore, they will have a more volatile revenue than others, and the profit will also be higher.

Credit loans $(\beta=0.830 ; \mathrm{p}<0.05)$ accessing credit in Laos are challenging; businesses assess it as a factor hindering their business operations. In model (6), the results show that the more credit capital firms borrow from the official market, the more efficiently they operate. This shows that capital is an essential factor in creating conditions for Laos businesses to develop more.

\section{Conclusions}

Internationalization is an activity which is taking place on a global scale and with a fast rate of spread at a time when the Industrial Revolution 4.0 has entered the "accelerating" phase. The expansion of business to international markets not only brings many opportunities to seek profits, exploit inherent competitive advantages, set up new product roadmaps, and take advantage of economies of scale. Internationalization also helps businesses exploit resources in partner countries that they do not have or have no access to. However, internationalization is two sides of the same problem, so there are always costs associated with the mentioned opportunities.

Most businesses in Laos are private, operating in the fields of retail or food and accommodation services, so the level of access to knowledge to penetrate international markets is quite limited. These businesses are of small-scale in nature and operate in small markets, so they lack resources to invest in product development or expansion activities, or take advantage of their country's competitive advantages. Besides, the main exports in Laos are textiles and minerals, so part of the wage advantage has moved to Laos which is the only inland country in Southeast Asia.

The regression analysis shows that internationalization affects the business performance of businesses in Laos; specifically, if the internationalization level is lower than 0.4374 , it will have to spend much money and costs for more market access but will recover and benefit from internationalization if the level of internationalization is higher than 0.9131 . Firms with a high rate of centralization 
and internationalization will have higher profits than others, and more firms with formal credit access will operate more efficiently.

The enterprises in the research show that enterprises with a high concentration of ownership and involved in internationalization activities will bring better results than those enterprises which are not involved in internationalization activities if they continue to maintain business activities in the domestic market. Laos is a country with a potentially low-cost workforce that has yet to be fully exploited, most of these workforce is operating in the agricultural sector in the rural areas, so there is still a waste of resources and no value increase as much as in other processing and manufacturing activities. If the Laos government supports enterprises to expand production activities such as textiles and garments (which contributes most value to Laos' economy) and take advantage of the cheap labor force in society, then there will be more success in the future.

Official financial sources are obstacles for businesses in Laos which intend to to expand the business because access to these capital sources is complicated, so businesses almost use capital extracted from corporate profits or the managers themselves, while the capital taken from these sources is limited. The Laos government needs ways to manage credit and provide credible sources for businesses in this country to have better access. Enterprises in Laos are constrained by inaccessible capital, while the abundant labor force cannot be exploited, which makes production in Laos extremely small, mostly as trading activities, then it will be difficult for the economy to achieve ideal growth.

\section{References}

Almodóvar, P., \& Rugman, A. M. (2014). The M Curve and the Performance of Spanish International New Ventures. British Journal of Management, 25(S1). DOI: 10.1111/14678551.12022

Altaf, N., \& Shah, F. A. (2015). Internationalization and firm performance of Indian firms: Does product diversity matter?. Pacific Science Review B: Humanities and Social Sciences, 1(2), 76-84.

Cameron, A. C., \& Trivedi, P. K. (2005). Microeconometrics: Methods and Applications. Cambridge, UK: Cambridge University Press. DOI: 10.1017/CBO9780511811241

Capar, N., \& Kotabe, M. (2003). The relationship between international diversification and performance in service firms. Journal of International Business Studies. Vol.34, pp 345-355.

Cyert, R. M. \& March, J. G. (1963). A behavioral Theory of the Firm. Englewood Cliffs, NJ: Prentice Hall.

Chung, C. C., Lu, J. W., \& Beamish, P. W. (2008). Multinational networks during times of economic crisis versus stability. Management International Review, 48(3), 279-296.
Chung, C. C., Lee, S. H., Beamish, P. W., Southam, C., \& Nam, D. D. (2013). Pitting real options theory against risk diversification theory: International diversification and joint ownership control in economic crisis. Journal of World Business, 48(1), 122-136.

Chung, C. C., Lee, S. H., Beamish, P. W., \& Isobe, T. (2010). Subsidiary expansion/contraction during times of economic crisis. Journal of International Business Studies, 41(3), 500-516.

Chiao, Y. C., Yang, K. P., \& Yu, C. M. J. (2006). Performance, internationalization, and firm-specific advantages of SMEs in a newly-industrialized economy. Small Business Economics, 26(5), 475-492.

Collins, J. M. (1990). A market performance comparison of US firms active in domestic, developed and developing countries. Journal of International Business Studies, 21(2), 271-287.

Contractor, F. J. (2012). Why do multinational firms exist? A theory note about the effect of multinational expansion on performance and recent methodological critiques. Global Strategy Journal, 2(4), 318-331.

Contractor, F. J., Kundu, S. K., \& Hsu, C. C. (2003). A threestage theory of international expansion: The link between multinationality and performance in the service sector. Journal of International Business Studies, 34(1), 5-18.

Contractor, F. J., Kumar, V., \& Kundu, S. K. (2007). Nature of the relationship between international expansion and performance: The case of emerging market firms. Journal of World Business, 42(4), 401-417.

Dahya, J., Dimitrov, O., \& McConnell, J. J. (2008). Dominant shareholders, corporate boards, and corporate value: A crosscountry analysis. Journal of Financial Economics, 87(1), 73-100.

Do, T. T. (2020). Critical Factors Affecting the Salaries of Employees of Manufacturing Enterprises in Vietnam. Journal of Asian Finance, Economics, and Business, 7(6), 485-494. https://doi.org/10.13106/jafeb.2020.vol7.no6.485

Fernández-Olmos, M., Gargallo-Castel, A., \& Giner-Bagües, E. (2016). Internationalisation and performance in Spanish family SMES: The W-curve. BRQ Business Research Quarterly, 19(2), 122-136.

Grant, R. M., Jammine, A. P., \& Thomas, H. (1988). Diversity, diversification, and profitability among British manufacturing companies, 1972-1984. Academy of Management Journal, 31(4), 771-801.

Glaum, M., \& Oesterle, M. J. (2007). 40 years of research on internationalization and firm performance: More questions than answers? Management International Review, 47, 307-317. https://doi.org/10.1007/s11575-007-0018-0

Gorton, G., \& Kahl, M. (2008). Blockholder Scarcity, Takeovers, and Ownership Structures. Journal of Financial \& Quantitative Analysis, 43(4), 937-974

Guillén, M. F., \& García-Canal, E. (2009). The American model of the multinational firm and the "new" multinationals from 
emerging economies. Academy of Management Perspectives, 23(2), 23-35.

Hsu, W. T., Chen, H. L., \& Cheng, C. Y. (2013). Internationalization and firm performance of SMEs: The moderating effects of CEO attributes. Journal of World Business, 48(1), 1-12.

Hitt, M. A., Hoskisson, R. E., \& Kim, H. (1997). International diversification: Effects on innovation and firm performance in product-diversified firms. Academy of Management journal, 40(4), 767-798.

Hymer, S. H. (1976). The International Operations of National Firms: A Study of Direct Foreign Investment. Cambridge. Cambridge, MA: MIT Press

Johanson, J., \& Vahlne, J. E. (1977). The internationalization process of the firm-A model of knowledge development and increasing foreign market commitments. Journal of International Business Studies, 8(1), 23-32.

Mathews, J. A. (2002). Dragon multinational: A new model for global growth. Oxford, UK: Oxford University Press.

Michel, A., \& Shaked, I. (1986). Multinational corporations vs. domestic corporations: Financial performance and characteristics. Journal of International Business Studies, 17(3), 89-100.

Nguyen, T. N. L., \& Nguyen, V. C. (2020). The Determinants of Profitability in Listed Enterprises: A Study from Vietnamese Stock Exchange. Journal of Asian Finance, Economics, and Business, 7(1), 47-58. https://doi.org/10.13106/jafeb.2020. vol7.no1.47

Lauterbach, B., \& Vaninsky, A. (1999). Ownership structure and firm performance: Evidence from Israel. Journal of Management and Governance, 3(2), 189-201.

Li, L. (2007). Multinationality and performance: A synthetic review and research agenda. International Journal of Management Reviews, 9(2), 117-139.

Lin, W. T., Liu, Y., \& Cheng, K. Y. (2011). The internationalization and performance of a firm: Moderating effect of a firm's behavior. Journal of International Management, 17(1), 83-95.

Lu, J. W., \& Beamish, P. W. (2001). The internationalization and performance of SMEs. Strategic Management Journal, 22(6-7), 565-586.
Lu, J. W., \& Beamish, P. W. (2004). International diversification and firm performance: The S-curve hypothesis. Academy of Management Journal, 47(4), 598-609.

Pangarkar, N. (2008). Internationalization and performance of small-and medium-sized enterprises. Journal of World Business, 43(4), 475-485.

Peng, M. W., Wang, D. Y., \& Jiang, Y. (2008). An institution-based view of international business strategy: A focus on emerging economies. Journal of International Business Studies, 39(5), 920-936.

Tú, P. A. \& Uyên, T. T. T. (2017). A study of the relationship between internationalization and firm performance: A case study of firms in the service sector in Indonesia. VNU Journal of Science: Economics and Business, 33(1), 1-11.

Sanyal, S., Hisam, M. W., \& Baawain, A. M. S. (2020). Entrepreneurial Orientation, Network Competence and Human Capital: The Internationalization of SMEs in Oman. Journal of Asian Finance, Economics and Business, 7(8), 473-483. https:// doi.org/10.13106/jafeb.2020.vol7.no8.473

Stinchcombe, A. L. (1965) Social Structure and Organizations. Handbook of Organizations. Chicago, IL: Rand McNally. DOI: 10.1016/S0742-3322(00)17019-6

Wang, C. F., Chen, L. Y., \& Chang, S. C. (2011). International diversification and the market value of new product introduction. Journal of International Management, 17(4), 333-347.

Wooldridge, J. M. (1995). Selection corrections for panel data models under conditional mean independence assumptions. Journal of Econometrics, 68(1), 115-132.

Xiao, S. S., Jeong, I., Moon, J. J., Chung, C. C., \& Chung, J. (2013). Internationalization and performance of firms in China: Moderating effects of governance structure and the degree of centralized control. Journal of International Management, 19(2), 118-137.

Zahra, S. A., Ireland, R. D., \& Hitt, M. A. (2000). International expansion by new venture firms: International diversity, mode of market entry, technological learning, and performance. Academy of Management Journal, 43(5), 925-950. 